\title{
Representasi matematis mahasiswa calon guru dalam menyelesaikan masalah matematika
}

\section{Erni Puji Astuti ${ }^{1}$}

\begin{abstract}
Abstrak: Penelitian ini bertujuan untuk mengetahui deskripsi representasi matematis mahasiswa calon guru dalam menyelesaikan masalah matematika. Metode yang digunakan adalah kualitatif dengan pendekatan studi kasus. Data yang dikumpulkan yaitu hasil pekerjaan mahasiswa yang berupa hasil vignette. Snowball sampling sebagai teknik pengambilan subjek. Subjek dalam penelitian ini adalah tiga mahasiswa semester 3 Program Studi Pendidikan Matematika Universitas Muhammadiyah Purworejo. Teknik yang digunakan untuk mengumpulkan data adalah dokumentasi. Data dianalisis melalui tahap reduksi data, penyajian data, menarik kesimpulan, dan verifikasi. Hasil penelitian ini menunjukkan bahwa subjek S1 dan S2 dengan kemampuan akademik tinggi dan sedang mempunyai kemampuan representasi matematis yang baik karena memenuhi semua indikator representasi matematis. Kemampuan representasi matematis subjek S3 dengan kemampuan akademik rendah masih kurang karena tidak memenuhi semua indikator. Kemampuan representasi matematis tidak hanya dipengaruhi oleh kemampuan akademik, tetapi dipengaruhi juga oleh faktor lain seperti penggunaan media, pengalaman, dan latihan dalam menyelesaikan masalah matematika.
\end{abstract}

Kata kunci: Representasi Matematis; Calon Guru; Masalah Matematika; Vignette

Abstract: This case study aims to determine the description of the mathematical representation of prospective teachers in solving mathematical problems. The data collected is student's work in the form of vignette results. Snowball sampling is as the technique of taking subjects. Subjects in this study are three students in the third semester mathematics education program of Muhammadiyah University of Purworejo. The technique used to collect data is documentation. The data is analyzed through data reduction, data

\footnotetext{
${ }^{1}$ Universitas Muhammadiyah Purworejo, Purworejo, Indonesia, 3rniee.ast84@gmail.com
} 
display, conclusion, and verification. This study finds that the subject S1 and S2 with high and middle academic ability have good mathematical representation ability since they meet all the indicators of mathematical representation. While the mathematical representation of subject S3 with low academic ability is still less because S3 does not meet all of the indicators. The ability of the mathematical representation is not only influenced by academic ability, but also by other factors such as the use of media, experience, and drill in solving mathematics problems.

Keywords: Mathematical Representation; Prospective Teacher; Mathematics Problems; Vignette

\section{A. Pendahuluan}

Matematika merupakan salah satu mata pelajaran wajib yang ada dalam semua jenjang pendidikan mulai dari sekolah dasar (SD) hingga sekolah menengah atas (SMA). Berhasil atau tidaknya pembelajaran matematika bergantung pada proses pembelajaran. Dalam hal ini, guru memainkan peran sentral dalam pembelajaran matematika. Salah satu peran guru adalah membantu siswa memahami konsep dasar materi matematika. Untuk melaksanakan peran tersebut, seorang guru matematika dituntut memiliki pengetahuan dan kemampuan matematika yang memadai, salah satunya adalah kemampuan representasi matematis.

Representasi matematis merupakan bagian dari kemampuan dasar matematika yang harus dikembangkan baik oleh siswa, mahasiswa, ataupun guru. Hwang, Chen, Dung, dan Yang (2007) menyatakan bahwa keterampilan representasi adalah kunci sukses pemecahan masalah matematika. Representasi matematis berperan sebagai jalan dalam mengungkapkan ide matematis dan cara siswa dalam memahami dan menggunakan ide-ide matematisnya. Penelitian Wahyu, Amin dan Lukito (2017) menunjukan bahwa penggunaan representasi dalam bentuk model luas (area model) bisa membantu siswa memahami pembagian pecahan.

NCTM (2000) menyebutkan lima kemampuan matematika yang harus dimiliki siswa, yaitu: 1) belajar untuk berkomunikasi (mathematical communication); 2) belajar untuk bernalar (mathematical reasoning); 3) 
belajar untuk memecahkan masalah (mathematical problem solving); 4) belajar untuk mengaitkan ide (mathematical connection); 5) belajar untuk merepresentasikan ide-ide (mathematical representation). Dalam matematika siswa dituntut untuk memiliki kemampuan komunikasi matematis, sehingga siswa mampu bernalar dengan baik. Penalaran merupakan alat yang penting dalam matematika dan kehidupan seharihari. Kemampuan bernalar yang baik merupakan kunci bagi siswa untuk dapat memecahkan masalah, mengkaitkan berbagai ide dalam matematika, selanjutnya siswa dapat merepresentasikan ide-ide yang dimilikinya. Agar siswa mencapai kelima kemampuan tersebut dalam pembelajaran, guru dituntut terlebih dahulu menguasainya.

Mahasiswa calon guru matematika harus memiliki kemampuan representasi matematis yang baik yaitu mengetahui bagaimana sebuah ide matematis dapat direpresentasikan untuk memfasilitasi siswanya agar lebih memahami ide tersebut. Guru harus mampu menerjemahkan ideide matematika yang sulit dalam sebuah representasi yang dapat dipahami oleh siswanya. Untuk dapat melakukan itu, calon guru harus difasilitasi dengan kemampuan representasi yang berguna dalam mengajarkan matematika, seperti masalah berupa cerita, gambar, situasi serta materi yang bersifat nyata.

Menurut McCoy, Baker dan Little (1996), cara terbaik untuk membantu siswa memahami matematika melalui representasi adalah dengan mendorong mereka untuk menemukan atau membuat suatu representasi sebagai alat atau cara berpikir dalam mengkomunikasikan gagasan matematika. Dengan demikian, kemampuan representasi ini diperlukan untuk membantu mereka dalam menyampaikan ide-ide sehingga tertuang dalam bentuk tulisan atau mengubah dari abstrak ke konkret sehingga dapat mempermudah dalam memahaminya. Kemampuan representasi ini juga membantu menemukan dan membuat suatu alat atau cara berpikir agar ide-ide gagasan matematis ini tersampaikan.

Menurut Hiebert dan Carpenter (1992), representasi dapat dinyatakan sebagai representasi internal dan eksternal. Berpikir tentang ide matematika yang kemudian dikomunikasikan memerlukan representasi eksternal yang wujudnya antara lain verbal, gambar dan benda konkrit. Berpikir tentang ide matematika yang memungkinkan 
pikiran seseorang bekerja atas dasar ide tersebut merupakan representasi internal. Representasi internal tidak dapat diamati karena ada di dalam mental.

Menurut Kartini (2009) representasi dapat digolongkan menjadi tiga, yaitu: 1) representasi visual (gambar, diagram grafik, atau tabel), 2) representasi simbolik (pernyataan matematik/notasi matematik, numerik/simbol aljabar), dan 3) representasi verbal (teks tertulis/katakata). Mokhamad dan Karunia (2015) menyatakan bahwa kemampuan representasi matematis adalah kemampuan menyajikan kembali notasi, simbol, tabel, gambar, grafik, diagram, persamaan atau ekspresi matematis lainnya ke dalam bentuk lain. Dalam penelitian ini, representasi matematis yang akan dinilai adalah representasi gambar, teks tertulis, persamaan atau ekspresi matematis.

Beberapa penelitian sudah dilakukan untuk menganalisis kemampuan representasi matematis mahasiswa calon guru. Salah satunya dilakukan oleh Hafiziani (2015). Penelitian tersebut membandingkan kemampuan representasi matematis mahasiswa calon guru yang diberikan pembelajaran CPA (Concrete Pictorial Abstract) dan pembelajaran konvensional berdasarkan kemampuan awal matematika. Hasilnya menunjukan bahwa kemampuan mahasiswa calon guru yang diberikan pembelajaran CPA memiliki kemampuan representasi matematis yang lebih baik. Penelitian ini hanya mendeskripsikan kemampuan representasi matematis mahasiswa calon guru berdasarkan kemampuan matematika yang ditentukan dari indeks prestasi kumulatif (IPK).

Mengingat pentingnya kemampuan representasi matematis dan mahasiswa calon guru yang dipersiapkan untuk menjadi guru yang bisa membantu siswa merepresentasikan ide matematis dalam pembelajaran, penelitian ini bertujuan untuk mengetahui kemampuan representasi matematis mahasiswa calon guru dalam menyelesaikan masalah matematika. Karena peran guru menentukan kualitas pembelajaran, maka hasil penelitian ini diharapkan dapat memberikan gambaran kualitas calon guru ketika menyampaikan konsep di kelas. Selain itu, dapat memberikan wawasan kepada calon guru untuk lebih meningkatkan kemampuan representasi matematisnya melalui pengalaman dan latihan dalam menyelesaikan masalah matematika agar memiliki kemampuan representasi matematis yang baik. 


\section{B. Metode Penelitian}

Penelitian ini menggunakan pendekatan kualitatif. Penelitian kualitatif adalah penelitian yang digunakan untuk meneliti pada kondisi obyek yang alamiah, dimana peneliti adalah sebagai instrumen kunci dan hasil penelitian kualitatif lebih menekankan makna dari pada generalisasi (Sugiyono, 2010). Jenis penelitian yang digunakan dalam penelitian ini adalah studi kasus. Studi kasus adalah deskripsi dan analisis intensif terhadap suatu fenomena, unit sosial, atau sistem yang dibatasi oleh tempat dan waktu (Bloomberg \& Volpe, 2012). Desain studi kasus dalam penelitian ini dilakukan untuk memperoleh pemahaman mendalam dari situasi dan makna representasi matematis yang dapat dilihat dari hasil vignette, perhatian lebih diutamakan pada proses daripada hasil.

Snowball sampling digunakan sebagai teknik pengambilan subjek dalam penelitian ini. Subjek dalam penelitian ini adalah tiga mahasiswa semester 3 Program Studi Pendidikan Matematika Universitas Muhammadiyah Purworejo. Penentuan subjek dalam penelitian ini berdasarkan permasalahan yang diteliti yaitu tentang representasi matematis mahasiswa calon guru matematika. Kemampuan akademik mahasiswa sangat beragam sehingga subjek penelitian yang diambil terdiri dari 1 mahasiswa dengan kemampuan akademik tinggi (IPK $\geq 3,50)$, 1 mahasiswa dengan kemampuan akademik sedang $(3,00 \leq \operatorname{IPK}<3,50)$, dan 1 mahasiswa dengan kemampuan akademik rendah (IPK $<3,00)$.

Teknik yang digunakan untuk mengumpulkan data saat pelaksanaan penelitian adalah dokumentasi dan data hasil pekerjaan mahasiswa yang berupa hasil vignette. Vignette merupakan suatu skenario yang berisi cerita/kasus/percakapan yang terjadi di dalam kelas yang dituliskan pada lembaran kertas. Indikator representasi matematis dalam penelitian, yaitu: membuat gambar bangun geometri untuk memperjelas masalah memfasilitasi penyelesaian (representasi gambar); membuat situasi masalah berdasarkan data atau representasi yang diberikan, menulis interpretasi dari suatu representasi, dan menulis langkah-langkah penyelesaian masalah matematis dengan kata-kata (reprentasi kata atau teks tertulis); membuat persamaan atau model matematis dari representasi lain yang diberikan dan penyelesaian masalah dengan 
melibatkan ekspresi matematis (representasi persamaan atau ekspresi matematis).

Teknik analisis data menurut Miles dan Huberman (1992) analisis data kualitatif dilakukan secara interaktif dan berlangsung secara terusmenerus sampai tuntas, sehingga datanya sudah jenuh. Data dianalisis melalui tahap reduksi data, penyajian data, menarik kesimpulan, dan verifikasi

\section{Temuan dan Pembahasan}

Soal yang digunakan untuk mengukur kemampuan representasi matematis mahasiswa calon guru matematika adalah soal geometri analitik bidang sebagai berikut.

Tentukan persamaan garis singgung lingkaran $x^{2}+y^{2}+2 y-3=0$ yang melalui titik $A(2,1)$ !

Berikut ini adalah contoh jawaban subjek S1 yang dapat dilihat pada Gambar 1.

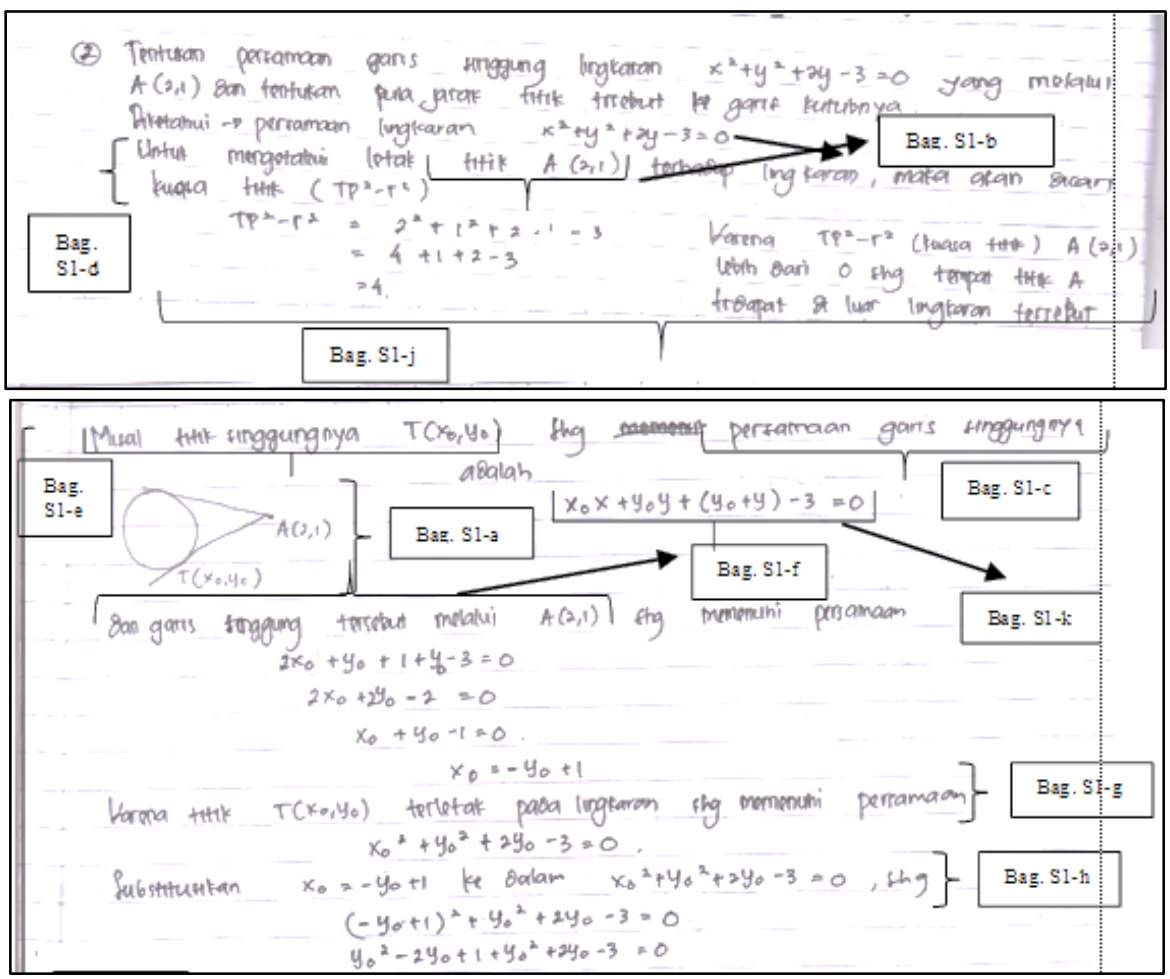




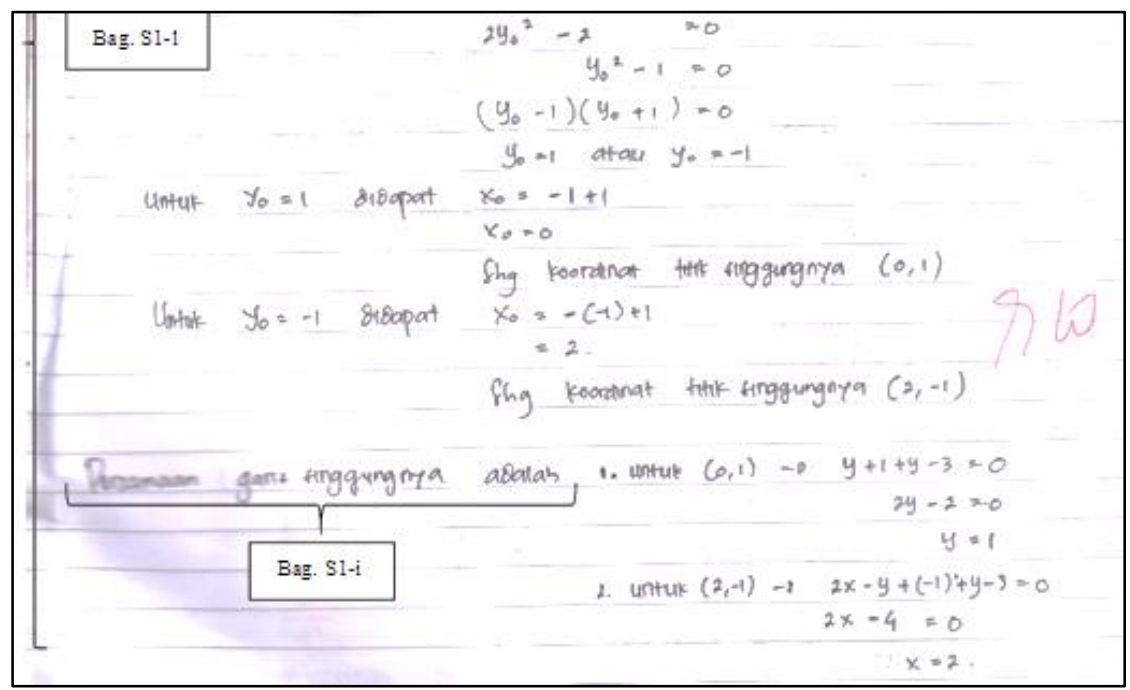

Gambar 1. Jawaban Subjek 1

Berdasarkan jawaban subjek S1 pada Bag. S1-a di atas, subjek S1 sudah dapat membuat gambar bangun geometri untuk memperjelas masalah dan memfasilitasi penyelesaian. Dalam hal ini, subjek S1 dapat menginterpretasi soal ke dalam bentuk gambar sehingga akan lebih mudah dalam menyelesaikan masalah.

Jawaban subjek S1 pada Bag. S1-b di atas, terlihat bahwa subjek S1 sudah dapat membuat situasi masalah berdasarkan data atau representasi yang diberikan. Hal ini terbukti bahwa subjek S1 dapat menuliskan informasi yang ditemukan dalam soal yaitu persamaan lingkaran $x^{2}+y^{2}+2 y-3=0$ dan titik $A(2,1)$ yang diketahui dalam soal.

Pada jawaban subjek S-1 Bag. S1-c tampak bahwa subjek S1 sudah dapat menulis interpretasi dari suatu representasi. Artinya dari informasi yang telah dituliskan sebelumnya, subjek S1 dapat mengetahui arah dari pertanyaan yang ada di dalam soal. Terbukti subjek S1 dapat menemukan dan menuliskan masalah apa yang harus diselesaikan dalam soal yaitu menentukan persamaan garis singgung lingkaran.

Jawaban subjek S1 pada Bag. S1-d sampai dengan Bag. S1-i menunjukan bahwa subjek S1 sudah dapat menulis langkah-langkah penyelesaian masalah matematis dengan kata-kata. Dalam hal ini, subjek 
S1 sudah menuliskan tahapan-tahapan yang harus dilakukan dalam menyelesaikan masalah secara sistematis.

Jawaban subjek S1 pada Bag. S1-k, subjek S1 sudah dapat membuat persamaan atau model matematis dari representasi lain yang diberikan. Pada jawaban Bag. S1-j terlihat bahwa ketika subjek S1 sudah mengetahui informasi yang diperoleh pada soal, maka langkah yang dilakukan subjek S1 adalah mencari kuasa titik A terhadap lingkaran. Karena kuasa titik A terhadap lingkaran terletak di luar lingkaran. Sedangkan pada Bag. S1-k, setelah subjek S1 mengetahui bahwa kuasa titik $A$ terhadap lingkaran berada di luar, maka langkah selanjutnya adalah subjek S1 memisalkan ada sebuah titik yang terletak pada lingkaran dengan mengambil sebarang titik yaitu $T\left(x_{0}, y_{0}\right)$. Kemudian subjek $\mathrm{S} 1$ menetukan persamaan garis singgung lingkaran di titik $T$ dengan membuat model matematikanya yaitu $x_{0} x+y_{0} y+\left(y_{0}+y\right)-3=0$.

Pada jawaban subjek S1 Bag. S1-I, subjek S1 sudah dapat melakukan penyelesaian masalah dengan melibatkan ekspresi matematis. Terbukti subjek S1 mampu menyelesaikan masalah dengan menuliskan prosesnya secara sistematis dan menggunakan model matematika. Dengan tahapan yang runtut, subjek S1 mampu menyelesaikan masalah dengan benar.

Berikut ini (Gambar 2) adalah contoh jawaban subjek S2.

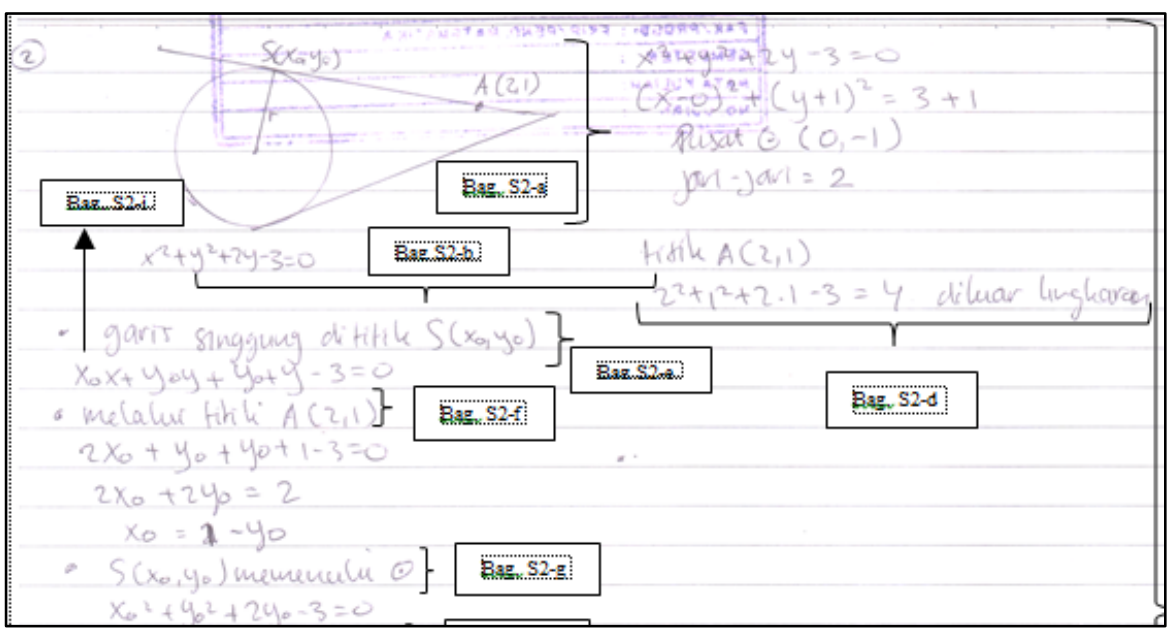




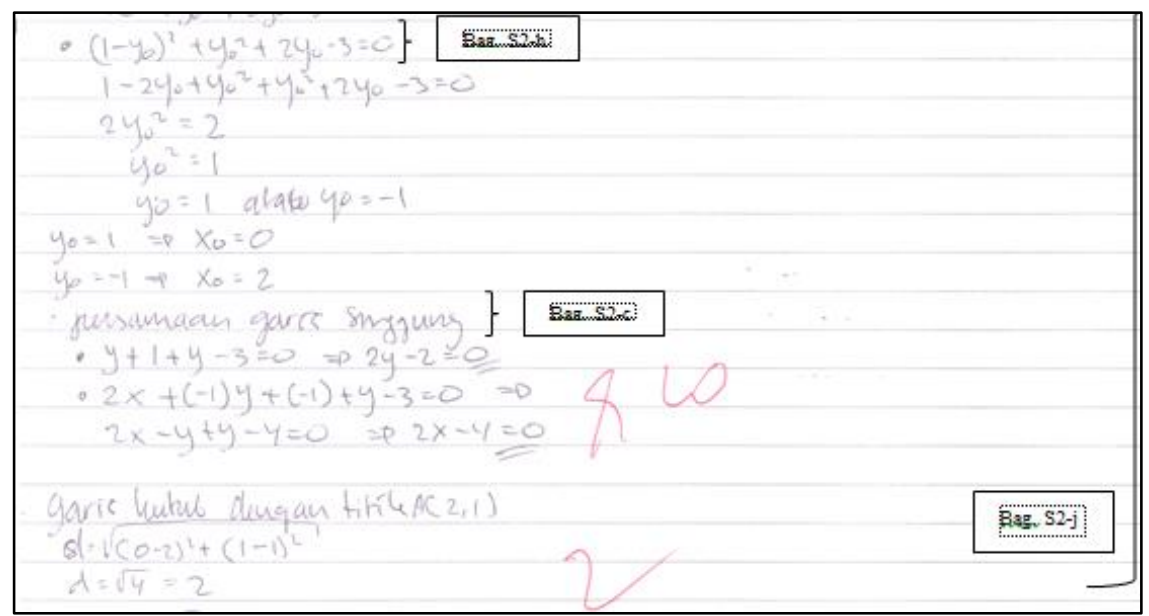

Gambar 2. Jawaban Subjek S2

Jawaban subjek S2 Bag. S2-a menunjukan subjek S2 sudah dapat membuat gambar bangun geometri untuk memperjelas masalah dan memfasilitasi penyelesaian. Dapat dikatakan bahwa subjek S2 dapat menginterpretasi soal ke dalam bentuk gambar sehingga akan lebih mudah dalam menyelesaikan masalah.

Pada jawaban Bag. S2-b, subjek S2 sudah dapat membuat situasi masalah berdasarkan data atau representasi yang diberikan. Subjek S2 juga dapat menuliskan informasi yang ditemukan dalam soal yaitu persamaan lingkaran $x^{2}+y^{2}+2 y-3=0$ dan titik $A(2,1)$ yang diketahui dalam soal. Pada jawaban Bag. S2-c, subjek S2 sudah dapat menulis interpretasi dari suatu representasi. Terbukti subjek S2 dapat menuliskan masalah apa yang harus diselesaikan dalam soal, yaitu mencari persamaan garis singgung lingkaran. Subjek S2 dapat menentukan masalah yang akan diselesaikan berdasarkan informasi yang telah dituliskan sebelumnya.

Jawaban Bag. S2-d sampai dengan Bag. S2-h, terlihat bahwa Subjek S2 dapat menulis langkah-langkah penyelesaian masalah matematis dengan kata-kata. Dalam hal ini subjek S2 sudah menuliskan tahapantahapan yang harus dilakukan dalam menyelesaikan masalah secara sistematis. Pada jawaban subjek S2 Bag. S2-i, subjek S2 sudah dapat membuat persamaan atau model matematis dari representasi lain yang diberikan. Setelah subjek S2 mengetahui informasi pada soal, maka langkah yang dilakukan subjek S2 adalah mencari kuasa titik A terhadap 
lingkaran. Karena kuasa titik A terhadap lingkaran terletak di luar lingkaran, maka langkah selanjutnya yang dilakukan adalah Subjek S2 memisalkan ada sebuah titik yang terletak pada lingkaran dengan mengambil sebarang titik yaitu $S\left(x_{0}, y_{0}\right)$. Kemudian subjek S2 mennetukan persamaan garis singgung lingkaran di titik $\mathrm{S}$ dengan membuat model matematikanya yaitu $x_{0} x+y_{0} y+\left(y_{0}+y\right)-3=0$.

Berdasarkan jawaban subjek S2 pada Bag. S2-j terlihat bahwa subjek S2 sudah dapat melakukan penyelesaian masalah dengan melibatkan ekspresi matematis. Terbukti subjek S2 mampu menyelesaikan masalah dengan menuliskan prosesnya secara sistematis dan dengan menggunakan model matematika. Proses penyelesaian yang dilakukan subjek S2 dilakukan secara runtut sehingga subjek S2 dapat menyelesaikan masalah dengan benar.

Berikut ini adalah contoh jawaban subjek S3 yang dapat dilihat pada Gambar 3.

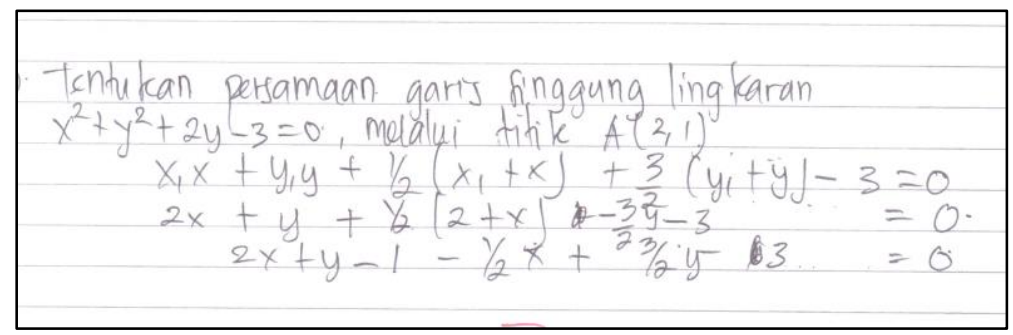

Gambar 3. Jawaban Subjek S3

Berdasarkan jawaban subjek S3 di atas maka dapat dikatakan bahwa subjek S3 belum dapat membuat gambar bangun geometri untuk memperjelas masalah dan memfasilitasi penyelesaian, belum dapat membuat situasi masalah berdasarkan data atau representasi yang diberikan, belum dapat menulis interpretasi dari suatu representasi, belum dapat menulis langkah-langkah penyelesaian masalah matematis dengan kata-kata, belum dapat membuat persamaan atau model matematis dari representasi lain yang diberikan, dan belum dapat menyelesaian masalah dengan melibatkan ekspresi matematis.

Subjek S3 langsung menuliskan penyelesaian masalahnya tanpa menuliskan informasi yang ada dalam soal. Akibatnya subjek S3 salah dalam melakukan penyelesaian masalah. Subjek S3 tidak menentukan kuasa titik $A$ terhadap lingkaran sehingga subjek S3 tidak mengetahui letak titik A terhadap lingkaran. Subjek S3 menyelesaikan soal tersebut 
dengan menggunakan aturan membagi adil. Subjek S3 berpendapat bahwa titik A terletak pada lingkaran. Padahal kuasa titik A terhadap lingkaran tersebut berada di luar. Seharusnya subjek S3 memisalkan titik singgungnya terlebih dahulu, setelah itu baru menetukan penyelesaian masalahnya.

Berdasarkan beberapa temuan dari penelitian ini, maka subjek S1 dan subjek S2 memenuhi semua indikator representasi matematis. Ini berarti bahwa kemampuan representasi matematis subjek S1 dengan kemampuan akademik tinggi dan subjek S2 dengan kemampuan akademik sedang memiliki kemampuan representasi matematis baik. Sedangkan kemampuan representasi matematis subjek S3 dengan kemampuan akademik rendah, berdasarkan analisis vignette masih kurang karena tidak satupun indikator representasi matematis yang muncul dalam jawaban subjek S3. Salah satu indikator yang tidak terpenuhi oleh subjek S3 membuat gambar bangun geometri untuk memperjelas masalah dan memfasilitasi penyelesaian. Hal ini sesuai dengan penelitian yang dilakukan oleh Puji (2016) dimana hasil penelitiannya menunjukkan bahwa kemampuan representasi gambar mahasiswa masih belum menunjukkan peningkatan yang signifikan. Hasil tes menunjukkan bahwa merepresentasikan objek dalam bentuk gambar masih merupakan sesuatu yang dianggap sulit oleh mahasiswa.

Kemampuan representasi matematis mahasiswa tidak hanya dipengaruhi oleh kemampuan akademik saja tetapi bisa juga dipengaruhi oleh faktor lain seperti penggunaan media dalam pembelajaran dan pengalaman atau latihan dalam menyelesaikan masalah matematika. Representasi matematis dapat ditingkatkan salah satunya menggunakan suatu media dalam pembelajaran. Hal ini sesuai dengan penelitian yang dilakukan oleh Anggun dan Eka (2015). Hasil penelitiannya menunjukkan bahwa pembelajaran menggunakan media GeoGebra berhasil meningkatkan kemapuan representasi matematis mahasiswa. Untuk meningkatkan kemampuan representasi matematis mahasiswa calon guru, diperlukan media dalam pembelajaran dan memfasilitasi pengalaman yang lebih dalam memecahkan masalah matematika. Berdasarkan hasil penelitian ini, kemampuan representasi matematis sangat penting untuk dimiliki mahasiswa calon guru matematika agar dapat membuat gambar bangun geometri dalam memperjelas masalah 
untuk memfasilitasi penyelesaian, menuliskan informasi berdasarkan data yang ada, menulis langkah-langkah penyelesaian masalah matematis, membuat persamaan atau model matematis, dan menyelesaikan masalah dengan melibatkan ekspresi matematis.

\section{Simpulan}

Berdasarkan hasil penelitian dan pembahasan, kemampuan representasi matematis subjek S1 dengan kemampuan akademik tinggi dan subjek S2 dengan kemampuan akademik sedang, berdasarkan hasil vignette, menunjukkan bahwa subjek S1 dan S2 mempunyai kemampuan representasi matematis yang baik karena memenuhi semua indikator representasi matematis. Sedangkan kemampuan representasi matematis subjek S3 dengan kemampuan akademik rendah masih kurang karena berdasarkan analisis hasil vignette tidak memenuhi semua indikator. Kemampuan representasi matematis mahasiswa calon guru tidak hanya dipengaruhi oleh kemampuan akademiknya, tetapi dipengaruhi juga oleh faktor lain seperti media pembelajaran yang digunakan, pengalaman, dan latihan. Dalam hal ini, diperlukan media dalam pembelajaran dan banyak latihan dalam menyelesaikan masalah matematis agar memiliki kemampuan representasi matematis yang baik. Mahasiswa calon guru matematika hendaknya mempunyai kemampuan representasi matematis yang baik agar bisa membantu siswa membuat gambar bangun geometri dalam memperjelas masalah untuk memfasilitasi penyelesaian, menuliskan informasi berdasarkan data yang ada, menulis langkahlangkah penyelesaian masalah matematis, membuat persamaan atau model matematis, dan menyelesaikan masalah dengan melibatkan ekspresi matematis.

\section{Daftar Pustaka}

Anggun, B. K. \& Eka, S. (2015). Peningkatan kemampuan representasi matematis mahasiswa menggunakan media program geogebra pada mata kuliah geometri transformasi. Jurnal Khazanah Pendidikan, 8 (2), 115. 
Bloomberg, L. D., \& Volpe, M. (2012). Completing your qualitative dissertation: A road map from beginning to end. London: Sage Publications.

Hafiziani, E. P. (2015). The influence of Concrete Pictorial Abstract (CPA) approach to the mathematical representation ability achievement of the pre-service teachers at elementary school. International Journal of Education and Research, 3 (6), 113-126.

Hiebert, J. \& Carpenter P. T. (1992). Learning and teaching with understanding. Dalam D. A. Grouws (Ed.) Handbook of Research on Mathematics Teaching and Learning. $(65-100)$. New York: Macmillan Publishing Company.

Hwang, W.-Y., Chen, N.-S., Dung, J.-J., \& Yang, Y.-L. (2007). Multiple representation skills and creativity effects on mathematical problem solving using a multimedia whiteboard system. Educational Technology \& Society, 10 (2), 191-212.

Kartini. (2009). Peranan representasi dalam pembelajaran matematika. Diakses di http://eprints.uny.ac.id/7036/1/P22-Kartini.pdf

McCoy, L.P., Baker, T.H., \& Little, L.S. (1996). Using multiple representations to communicate: An algebra chllenge. In P.C. Elliot (Ed). Communication in Mathematics, K-12 and Beyond. Reston, VA: National Council of Teachers of Mathematics.

Miles, B.M., \& Huberman, M.. (1992). Analisis data kualitatif buku sumber tentang metode-metode baru. Jakarta: UIP.

Mokhammad, R. Y \& Karunia, E. L. (2015). Penelitian pendidikan matematika. PT Revika Aditama: Bandung.

NCTM. (2000). Principles and standars for school mathematics. Reston, VA: NCTM.

Puji, L. (2016). Analisis kemampuan representasi matematis mahasiswa calon guru matematika yang mendapatkan model aktivitas investigasi autentik. Prosiding Seminar Nasional Matematika dan Pendidikan Matematika UNY 2016: MP 449- MP 456.

Sugiyono. (2010). Metode penelitian pendidikan (Pendekatan Kuantitatif, Kualitatif dan R\&D). Bandung: Alfabeta.

Wahyu, K., Amin, S.M., \& Lukito, A. (2017). Motivation cards to support students' understanding on fraction divisions. International Journal on Emerging Mathematics Education, 1(1), 99-120. DOI: http://dx.doi.org/10.12928/ijeme.v1i1.5760 